\title{
Adenotonsillektomi ve Adenoidektominin Mean Platelet Volüm (MPV) düzeyleri üzerine etkisi
}

\author{
Impact of Adenotonsillectomy and Adenoidectomy on Mean Platelet \\ Volume (MPV) Levels
}

\section{Serhan Derin', Murat Șahan'1, Hatice Topal'2, Yașar Topal²}

1 Department of Otolaryngology, Muğla Sıtkı Koçman University, Mugla, Turkey. 2 Department of Pediatrics, Muğla Sıtkı Koçman University, Mugla, Turkey.

\section{ÖZET}

Amaç: Adenotonsiller hipertrofiler (ATH) kardiyopulmoner hastalıklar başta olmak üzere bir çok hastalığa neden olmaktadır. Daha önceki çalışmalar ATH li hastalarda pulmoner arter hipertansiyon insidansının arttığını ve adenotonsillektomi ile gerilediğini raporlamışlardır. Mean platelet volüm (MPV) son çalışmalarda bir çok kardiyak hastalıkta olduğu gibi pulmoner hipertansiyonda da prognostik kriter olma yolundadır. Büyük trombositler daha fazla proinflamatuar, protrombotik ve vazomotor aktiviteye sahiptir. Bu çalışmanın amacı adenotonsillektomi ve adenoidektomi operasyonu sonrası MPV değişimleri olup olmadığını araştırmaktır.

Hastalar ve Metod: Bu çalışmada ATH de MPV değerleri ölçüldü ve cerrahi tedavilerin MPV değerleri üzerine etkisi araştırıldı. Otuz beş hastaya adenotonsillektomi, 30 hastaya adenoidektomi yapıldı. Preoperatif ve postoperatif 3. ay hemogram sonuçları karşılaştırıldı.

Bulgular: Hastaların ortalama yaşı $6.51 \pm 2.75$ (2-16)'tı. Operasyon sonrası MPV değerlerindeki düşüş istatistiksel olarak anlamlıydı. (Preoperatif 9,75 $\pm 0,95$; Postoperatif 8,14 $\pm 1,25)$. 0,05

Sonuç: Adenotonsillektomi ve adenoidektomi operasyonları kardiyopulmoner komplikasyon belirteci olan MPV değerlerini etkili şekilde düşürmektedir.

\section{ABSTRACT}

Objective: Adenotonsillar hypertrophy (ATH) leads to many disorders, especially cardiopulmonary diseases. Previous studies have reported the increase in pulmonary hypertension incidence in patients with ATH, as well as a decrease after adenotonsillectomy. Mean platelet volume (MPV) is becoming a prognostic indicator for pulmonary hypertension in recent studies, as it is in most cardiac diseases. It is known that larger platelets have increased proinflammatory and vasomotor activity, and prothrombotic potential. The purpose of this study to investigate whether of MPV levels changes after adenotonsillectomy and adenoidectomy.

Methods: In this study, MPV values in patients with ATH were evaluated, and the impact of surgical treatment on MPV levels was analyzed. Thirty-five patients had adenotonsillectomy, while the remaining 30 patients had adenoidectomy. The preoperative and postoperative third month hemogram results were compared.

Results: The mean age of the children was $6.51 \pm 2.75$ (2-16) years. The decrease in MPV levels after the operation was statistically significant (Preoperative 9,75 $\pm 0,95$; Postoperative 8,14 $\pm 1,25$ ). 0,05

Conclusion: Adenotonsillectomy and adenoidectomy operations effectively reduce MPV levels that marker of cardiopulmoner complications.

Keywords: Mean platelet volume (MPV); Adenotonsillar hypertrophy; Adenotonsillectomy; Adenoidectomy.
Corresponding Author: Serhan Derin

Address: Dep. of Otolaryngology, Muğla Sıtkı Koçman Univ., Mugla E-mail: serhanderin@yahoo.com.tr
Başvuru Tarihi/Received: 24-08-2015

Kabul Tarihi/Accepted: 07-11-2015 


\section{INTRODUCTION}

Chronic adenotonsillar diseases are the most common cause of upper airway obstruction and obstructive sleep apnea syndrome in childhood. This clinical entity is related to many systemic diseases, especially cardiopulmonary diseases. ATH can cause cardiopulmonary diseases such as pulmonary arterial hypertension (PAH), cor pulmonale, right ventricular failure, valvular damage, and arrhythmia [1-3].

Upper airway obstructions, especially ATH in childhood, cause alveolar hypoventilation, which can result in chronic hypoxia and hypercarbia. Chronic hypoxia may cause PAH, cor pulmonale, and finally decompensated heart failure. These devastating complications were found to be reversible with tonsil and adenoid surgeries, which increased the importance of the treatment and also MPV as an early sign of these complications [1-8].

The MPV level, which is an indicator of platelet activation, is becoming more important lately

[9] because it has been demonstrated in many recent research studies that the MPV level is related to most systemic diseases especially cardiovascular complications $[4,8]$, as well as its role as part of the hemogram parameters and easily examined without an additional cost.

In the current study, the researchers analyzed the MPV levels of patients with adenotonsillar diseases, and changes in its level after surgical treatment, as well as the usage of it in clinical practice.

\section{MATERIALS AND METHODS}

The research protocol was submitted and approved by the Mugla Sıtkı Kocman University Ethics Committee, and was conducted in accordance with the ethical regulations of the Declaration of Helsinki.

\section{Study Population}

Sixty-five children who had adenoidectomy and adenotonsillectomy in our hospital between August 2011- December 2013 were the subjects of this study. In addition to routine ear, nose, throat physical examination, transnasal naso- pharyngeal endoscopy was performed on all patients to determine the size of the adenoids. Patients who cannot tolerate the endoscopy had lateral plain $\mathrm{x}$-ray for the nasopharynx. Subjects with the following criteria were included:

1. Children who had no chronic diseases such as diabetes mellitus, hepatic-renal disease, chronic heart disease, hematological diseases, thrombocytopenia, hypo/hyperthyroidism, bronchial asthma, obesity (those with a body mass index greater than the ninety-fifth percentile by age and gender), the use of antithrombotic medication, bleeding more than 50 mililiters during surgery, postoperative bleeding and recurrent adenoid hypertrophy;

2. Children who suffered from open mouth breathing, snoring, sleep apnea, difficulty in swallowing and a lack of appetite;

3. Children with adenoid hypertrophy with more than $50 \%$ nasopharynx obstruction without any other reasons that cause nasal obstruction such as turbinate hypertrophy, allergic rhinitis, septal deviation, and anatomic deformities;

4. Children with tonsil hypertrophy that caused oropharyngeal airway obstruction. Tonsil hypertrophies were graded according to the Brodsky scale [10] and those with grade 3-4 tonsil hypertrophy were included in the study.

Adenotonsillectomy and adenoidectomy were performed on all patients with same cold surgical technique and by same surgeon. Preoperative and postoperative third month hemograms were obtained. Preoperative and postoperative white blood cell counts (WBC), hemoglobin $(\mathrm{Hb})$, hematocrit $(\mathrm{Htc})$, platelet $(\mathrm{Plt})$ counts, and MPV levels were compared.

\section{Laboratory Analysis}

Blood samples were drawn from the antecubital vein and collected in EDTA containing tubes. Blood samples were drawn at 8:30-10:00 a.m. from fasting patients, and laboratory analyses were conducted on the same day until 2:00 p.m. to prevent in vitro platelet activation. The 
reference values for MPV ranged between 6.9 and $10.8 \mathrm{fL}$. Hemogram analysis was done with a BeckmanCoulter LH 780 Hematology Analyzer (BeckmanCoulter, Miami, FL).

\section{Statistical Analysis}

Data analysis was done with SPSS (Statistical Package for the Social Sciences) (Chicago, IL, USA) version 15.0. For normally distributed values, descriptive values were reported as mean \pm standard deviation. The comparison of dependent groups' values were done with paired-t test, and the independent groups' values were done with the independent sample t-test. $\mathrm{P}<0.05$ was accepted as statistically significant.

\section{RESULTS}

In the study, out of 65 patients, 30 (46.1\%) were male, whereas 35 (53.9\%) were female. Mean age was $6.51 \pm 2.75$ years (2-16). Thirtyfive patients had adenotonsillectomy, while the remaining 30 patients had adenoidectomy. Patients' preoperative mean hemogram valu- es were: WBC $8.66( \pm 2.61) \times 103 / \mu \mathrm{L}, \mathrm{Hg}$ level $12.98( \pm 0.87) \mathrm{g} / \mathrm{dL}, \mathrm{Htc} 38.11$ ( \pm 2.15$),$ PLT count $364.29( \pm 88.61) \times 103 / \mu \mathrm{L}$, and MPV 9.75 ( \pm 0.95$)$. Postoperative values were: WBC count7.69( \pm $2.25) \times 103 / \mu \mathrm{L}, \mathrm{Hg}$ level $12.73( \pm 0.75) \mathrm{g} / \mathrm{dL}, \mathrm{Htc}$ 38.49 ( \pm 2.21$)$, PLT count 316.71 ( \pm 68.77) $\times 103 /$ $\mu \mathrm{L}$, and MPV 8.14 ( \pm 1.25$)$. After surgery, MPV values of the patients with adenoid hypertrophy dropped from $9.66( \pm 1.00)$ to 7.98 ( \pm 0.88$)$, and in the patients with adenotonsillar hypertrophy, this value fell from $9.92( \pm 1.07)$ to $8.44( \pm 1.58)$. When these preoperative and postoperative values were compared, there was a statistically significant difference between WBC, Hb, PLT count, and MPV levels, while there was no difference between the Hct values. However, the difference of MPV values between patients with adenotonsillar hypertrophy and adenoid hypertrophy was not significant in both preoperatively $(p=0.23)$ and postoperatively $(p=0.21)$. The preoperative and postoperative values of the patients, including the $p$ values are shown in Table 1 . In addition, preoperative and postoperative MPV values are shown in Figure 1.

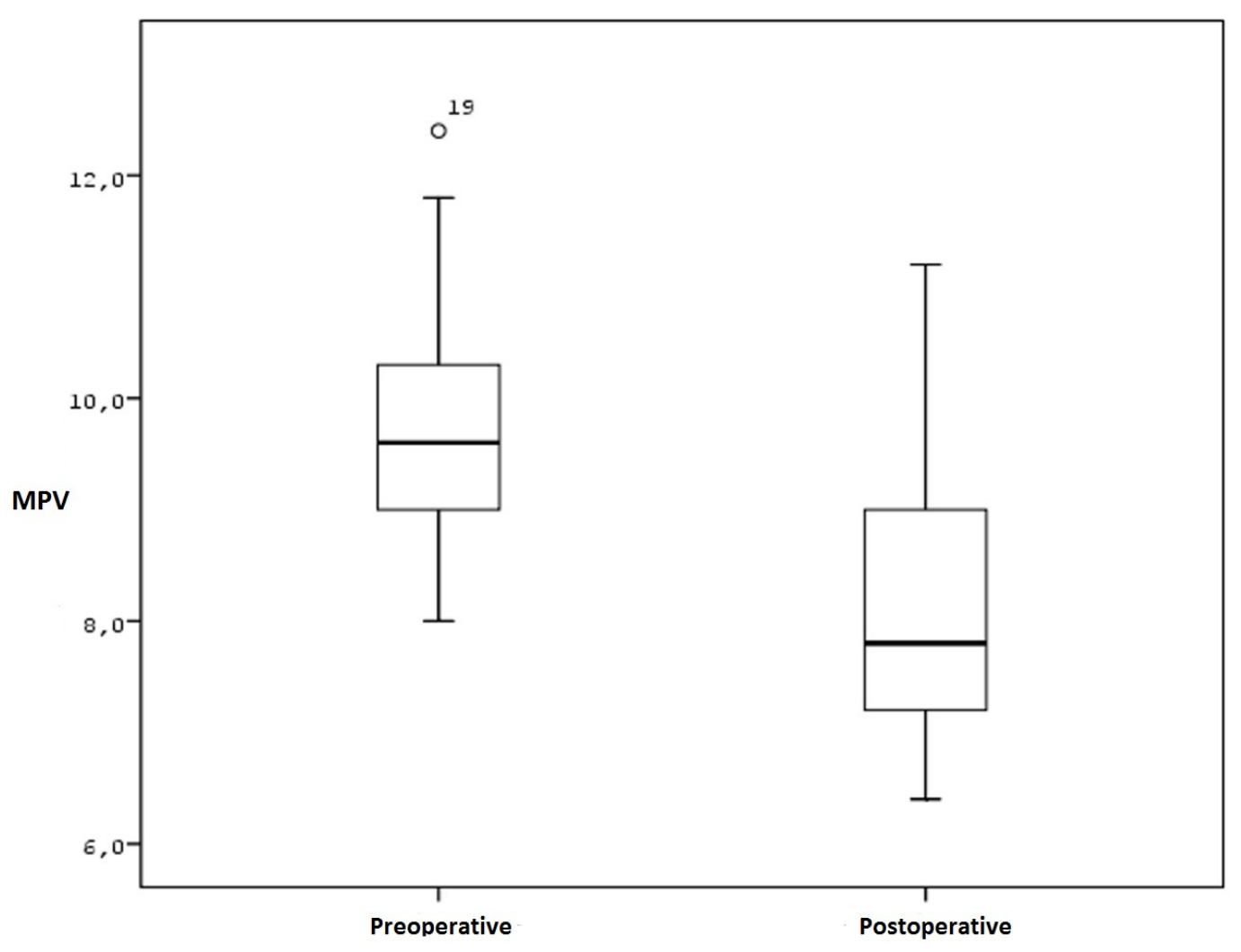

Figure 1: Comparison of MPV levels preoperatively compared postoperatively in the study groups. 


\begin{tabular}{|c|c|c|c|c|}
\hline & & Preoperative & Postoperative & $\mathbf{P}$ \\
\hline \multicolumn{2}{|c|}{$\begin{array}{l}\text { WBC count, } \\
\times 10^{3} / \mu \mathrm{L}\end{array}$} & $8,66 \pm 2,61$ & $7,69 \pm 2,25$ & $<0.05$ \\
\hline \multicolumn{2}{|c|}{$\begin{array}{l}\text { Hemoglobin level, } \\
\mathrm{g} / \mathrm{dL}\end{array}$} & $12,98 \pm 0,87$ & $12,73 \pm 0,75$ & $<0.05$ \\
\hline \multicolumn{2}{|c|}{ Hematocrit } & $38,11 \pm 2,15$ & $38,49 \pm 2,21$ & 0.134 \\
\hline \multicolumn{2}{|c|}{$\begin{array}{l}\text { Platelet count, } \\
\times 10^{3} / \mu \mathrm{L}\end{array}$} & $364,29 \pm 88,61$ & $\begin{array}{l}316,71 \pm \\
68,77\end{array}$ & $<0.05$ \\
\hline \multirow{3}{*}{$\begin{array}{l}\text { Mean } \\
\text { platelet } \\
\text { volume, } \\
\mathrm{fL}\end{array}$} & Total & $9,75 \pm 0,95$ & $8,14 \pm 1,25$ & $<0.05$ \\
\hline & $\mathrm{AH}$ & $9.66( \pm 1,00)$ & $7.98( \pm 0,88)$ & $<0.05$ \\
\hline & ATH & $9,92( \pm 1,07)$ & $8,44( \pm 1,58)$ & $<0.05$ \\
\hline
\end{tabular}

ATH: Adenotonsillar hypertrophy; AH: Adenoid hypertrophy

\section{DISCUSSION}

Adenotonsillar hypertrophy is a common cause of upper airway obstruction in childhood. Cardiopulmonary diseases may be seen in patients with chronic adenotonsillar hypertrophy that lead to severe obstructive sleep apnea [1-3, $5-8,11]$, among which pulmonary hypertension is the most well known [1-3, 5-8, 11-15]. Chronic alveolar hypoventilation results from long-term partial upper airway obstruction and leads to the paradoxical respiratory effect, hypercarbia and often hypoxemia [13-15]. This event causes respiratory acidosis, increase tendency for hypercoagulopathy and releasing vaso-active mediators, which leads to reversible or irreversible cardiopulmonary vascular changes. Hypoxemic pulmonary vasoconstriction may result in $\mathrm{PAH}$, right ventricle dysfunction, and even cor pulmonale [5-7]. MPV levels have been reported to be higher in patients with $\mathrm{PAH}$, nasal septal deviation and adenoid hypertrophy $[4,8,16,17,18]$.

High MPV values are indicative of larger and reactive platelets. It has been shown that large platelets contain more granules and adhesion molecules which have increased vasomotor activity, and prothrombotic potentials [19-22]. An increase in platelet activation and aggravation in $\mathrm{PAH}$, atherosclerosis, and atherothrombosis is reported in previous studies $[8,16,18,21$, 22]. Furthermore, the interaction of platelets with pulmonary endothelial cells is thought to contribute to pulmonary vascular changes [17]. After evaluating all those, high MPV level is an expected finding in $\mathrm{PAH}$ and a risk factor for vascular mortality.

Previous studies showed that adenotonsillectomy is curative treatment for $\mathrm{PAH}$, which is caused by adenotonsillar hypertrophy. After adenotonsillectomy, right ventricle function improves significantly $[2,3,5-7,23]$. Our study revealed that adenoidectomy and adenotonsillectomy cause a significant decrease in MPV levels. Onder et al showed that has not any effect of adenoidectomy on MPV levels. They explained this situation with chronic hypoxia exposure time is shorter in the pediatric population than in adult patients [24]. This statement does not sound reasonable while structural cardiac changes associated adenoid hypertrophy even may be seen in children. Likewise our results, Kucur at al. presented that adenoidectomy operation reducing impact on MPV levels and they emphasized that measurement of MPV may be considered a reliable guide for the assessment of $\mathrm{AH}$ [4]. Cengiz et al. statement that MPV levels lower than control group in adenotonsillar hypertrophy [25].

We think that elevated MPV in patients with ATH can be one the mechanisms of PAH and a candidate to monitor for cardiopulmonary complications. Additionally, the MPV levels that are determined by these future studies can help surgeons when they are making the decision adenotonsillectomy in terms of chronic diseases associated with the high MPV levels. MPV level may be available in for assessment of patients with ATH and the correct decision to undergo surgery in the future.

Limitation of this study is that the researchers did not utilize the measurement of pulmonary artery pressure and polysomnography. However, there are many other studies in which adenotonsillar hypertrophy leads to PAH and obstructive sleep apnea [1-3, 5-8, 11, 23].

As a result, this study showed that ATH have a significant effect on MPV values or with a another discourse, adenotonsillectomy and adenoidectomy reduces MPV levels significantly. 


\section{REFERENCES}

1. Tarlipinar A, Duman D, Uslu C, Egeli E. The effects of obstructive sleep apne syndrome dueto adenotonsillar hypertrophy on the cardiovascular system in children. Turk Journal of Pediatr 2011;53:359-63.

2. Abdel-Aziz M. Asymptomatic cardiopulmonary changes caused by adenoid hypertrophy. J Craniofac Surg 2011;22:1401-3.

3. Yilmaz MD, Onrat E, AltuntasA, et al. The effects of tonsillectomy and adenoidectomy on pulmonary arterial pressure in children. Am J Otolaryngol 2005;26:18-21.

4. Kucur C, Kulekci S, Zorlu A, Savran B, Oghan F, Yildirim N. Mean platelet volume levels in children with adenoid hypertrophy. J Craniofac Surg 2014;25:29-31.

5. Ugur MB, Dogan SM, et al. Effect of adenoidectomy and/or tonsillectomy on cardiac functions in children with obstructive sleep apnea. Orl J Otorhinolaryngol 2008;70:202-8.

6. Abd El-Moneim ES, Badawy BS, Atya M. The effect of adenoidectomy on right ventricular performance in children. Int J Pediatr Otorhinolaryngol 2009;73:15848

7. Koc S, Aytekin M, Kalay N, et al. The effect of adenotonsillectomy on right ventricle function and pulmonary artery pressure in children with adenotonsillar hypertrophy. Int J Pediatr Otorhinolaryngol 2012;76:45-8.

8. Varol E, Uysal BA, Ozaydin M. Platelet Indices in Patients With Pulmonary Arterial Hypertension. Clin Appl Thromb Hemost 2011;17:171-4.

9. Park Y, Schoene N, Harris W. Mean platelet volume as an indicator of platelet activation: Methodological issues. Platelets 2002;13:301-6.

10. Brodsky L. Modern assessment of tonsils and adenoids. Pediatr Clin North Am 1989;36:1551-69.

11. Guilleminault C, Korobkin R, Winkle R. A review of 50 children with obstructive sleep apnea syndrome. Lung 1981;159:275-87.

12. Pac A, Karadag A, Kurtaran H, Aktas D. Comparison of cardiac function and valvular damage in children with and without adenotonsillar hypertrophy. Int J Pediatr Otorhinolaryngol 2005;69:527-32.

13. Naiboglu B, Deveci S, Duman D, et al. Effect of upper airway obstruction on pulmonary arterial pressure in children. Int J Pediatr Otorhinolaryngol 2008:72;14259.
14. Miman MC, Kirazli T, Ozyurek R. Doppler echocardiography in adenotonsillar hypertrophy. Int J Pediatr Otorhinolaryngol 2000;54:21-6.

15. Görür K, Döven O, Unal M, Akkuş N, Ozcan C. Preoperative and postoperative cardiac and clinical findings of patients with adenotonsillar hypertrophy. Int J Pediatr Otorhinolaryngol 2001;59:41-6.

16. Can MM, Tanboğa IH, Demircan HC, et al. Enhanced hemostatic indices in patients with pulmonary arterial hypertension: an observational study. Thromb Res 2010;126:280-2.

17. Nakonechnicov S, Gabbasov Z, Chazova I, Popov E, Belenkov Yu. Platelet aggregation in patients with primary pulmonary hypertension. Blood Coagul Fibrinolysis 1996;7:225-7.

18. Kanbay A, Tutar N, Kaya E, et al. Mean platelet volume in patients with obstructive sleep apnea syndrome and its relationship with cardiovascular diseases. Blood Coagul Fibrinolysis 2013;24:532-6.

19. Thompson CB, Jacubowski JA, Quinn PG, Deykin D, Valeri CR. Platelet size is a determinant of platelet function. J Lab Clin Med 1983;101:205-13.

20. Bath PM, Butterworth RJ. Platelet size: measurement, physiology and vascular disease. Blood Coagul Fibrinolysis 1996;7:157-61.

21. Kilciler G, Genc H, Tapan S, et al. Mean platelet volume and its relationship with carotid atherosclerosis in subjects with non-alcoholic fatty liver disease. Ups J Med Sci 2010;115:253-9.

22. Lopes AA, Maeda NY, Almeida A, Jaeger R, Ebaid M, Chamone DF. Circulating platelet aggregates indicative of in vivo platelet activation in pulmonary hypertension. Angiology 1993;44:701-6.

23. Attia G, Ahmad MA, Saleh AB, Elsharkawy A. Impact of obstructive sleep apnea on global myocardial performance in children assessed by tissue Doppler imaging. Pediatr Cardiol. 2010;31:1025-36.

24. Onder S, Caypinar B, Yilmaz AS, Toros SZ, Oysu C. Relation of mean platelet volume with obstructive adenoid hypertrophy in children. Int J Pediatr Otorhinolaryngol. 2014 78:1449-51.

25. Cengiz C, Erhan Y, Murat T et al. Values of mean platelet volume in patients with chronic tonsillitis and adenoid hypertrophy. Pak J Med Sci 2013;29(2):569-72. 